\title{
CD177 wt Allele
}

National Cancer Institute

\section{Source}

National Cancer Institute. CD177 wt Allele. NCI Thesaurus. Code C113574.

Human CD177 wild-type allele is located in the vicinity of 19q13.31 and is approximately $10 \mathrm{~kb}$ in length. This allele, which encodes CD177 antigen protein, plays a role in platelet function and coagulation. Mutations in this gene are associated with polycythemia and hemorrhagic thrombocythemia. 